\title{
Cultural Contents in Communication and Culture Sections of High School Tieng Anh Series and Learners' Perceptions
}

\author{
Dinh Thi Truc Linh ${ }^{1}$ \\ ${ }^{1}$ Bachelor, School of Foreign Languages, Can Tho University, Vietnam
}

\begin{abstract}
This study aims to investigate two issues. Firstly, it identifies the cultural contents integrated into the sections Communication and Culture of the high school Tieng Anh series applying for the pilot program. Secondly, students' perceptions about these contents in terms of their presentation and usefulness are scrutinized. Content analysis, questionnaire, and interview were employed to collect data. 120 upper secondary students in the Mekong delta were contacted to answer the questionnaire. In the end, 12 of them were selected to attend the interviews. The findings revealed that the proportions of the sub-categories of sources and themes of culture are imbalance. Besides, students have positive attitudes towards these contents though they also indicate certain dissatisfactions regarding the way of presentation and the diversity of the contents. These findings provide implications for curriculum development, teachers' practice, and students' learning.
\end{abstract}

Keywords - cultural contents, high school Tieng Anh series, student's perceptions, students' suggestions, Communication and Culture section

\section{INTRODUCTION}

The relationship between language and culture is definitely a concern in the process of language teaching and learning. It is widely accepted that learning a language is not just about getting knowledge of phonetics, grammatical structures, or vocabulary. It has more to do with the culture underlining that language since successful use of language requires two factors: correctness and appropriateness (Brown, 1994). This indicates that language users must be aware of socio-cultural rules of use beside language codes to create effective communication. Therefore, language and culture are intertwined and teaching language must be in parallel with teaching culture as a result.

In Vietnamese teaching context, the position of culture has been acknowledged and appreciated in recent years. The Ministry of Education and Training (MoET) has emphasized in the Vietnam National Foreign Languages Project that by the year 2020, most Vietnamese youths who graduate from high schools, colleges and universities will have sufficient foreign language skills, can use them independently and confidently in communication, study and work in an integrated and multilingual and multicultural environment (MoET, 2008) base on the aim of the project. It can be inferred that the integration of intercultural communication in language teaching is advocated in the policy of Vietnam. Besides, there have been studies conducted to investigate language teachers' cultural awareness as well as practice in their teaching process with the aim of fostering culture teaching. Also, contents related to culture are now integral parts of the curriculum and they have been compiled and introduced in new series of textbooks, and the series of Tieng Anh textbooks used for high school can be seen as a representative. In these textbooks, cultural knowledge is designed as a section of the each unit together with a part of communication.

As a result of the pedagogical reform, the role of teacher and learners has been changed. Learner becomes the center in the teaching process whose voice should be considered since it has a direct impact on teaching practice and learning outcomes. Consequently, to be successful in transmitting culture knowledge, the understanding about teachers' perceptions and practices seem to be not enough. There is a need to gain insight into students' perspectives in order to have a complete view of the issue, especially when the amount of study related to this issue in Vietnam is limited. As a result, the research attempts to answer the following research questions:

(1) What are the cultural contents in Culture and Communication sections of high school Tieng Anh series? 
DOI: $\underline{10.51386 / 25815946 / \mathrm{ijsms}-\mathrm{v} 4 \mathrm{i} 5 \mathrm{p} 111}$

Volume: 4 Issue: 5

September to October 2021

https://www.ijsmsjournal.org

(2) What are students' perceptions of culture learning and their evaluations of the cultural contents in terms of their usefulness and ways of presentation?

\section{A. Culture and Cultural contents}

\section{LITERATURE REVIEW}

Culture has always been considered a vital part representing every country and its people. It is widely accepted that defining culture is not an easy job since it varies in terms. A well-known definition of culture given by Tyler $(1870$, p. 1) which is then cited by Avruch $(1998$, p. 6) stated that it is "the complex whole which includes knowledge, belief, art, morals, law, custom, and any other capabilities and habits acquired by man as a member of society". Montgomery and Reid-Thomas (1994) defined culture as the whole way of life consisting of all social practices that connect people in that society and differentiate them from others. These definitions give a general view that culture is a broad concept that refers to all of the things which relate to people's life in terms of spiritual and material. These things shape people's behaviors based on their beliefs, values, and norms about way of life and become distinct characteristics of that society.

Cortazzi and Jin (1999) stated that cultural contents are examined in terms of source and theme. Specifically, culture source is classified into three categories incorporating the Source culture, the Target culture, and the International target culture. The first type addresses the native culture of learners. Having the ability to express cultural values in their own culture thanks to knowledge of source culture contributes to the effectiveness of conversations or exchanges with foreigners. Nelson (1995) stated that recognizing and reflecting learners' source culture in language teaching is important since eliminating learners' cultural background means denying and devaluing their native culture, and hence their identities. The second type indicates the culture in countries where the target language (English) is used as the first language, for instance Britain, America, and Australia. It is obvious that achieving a language requires learners' mastering of its culture. The third type refers to the culture in countries where English is used as a lingua franca or international language. Knowing these varieties of culture helps learners to develop their intercultural competence in multicultural contexts.

Culture theme is divided into two types: big " $C$ " and little " $c$ ". As defined by Lee (2009), big "C" culture is about facts and statistics which can be observed easily relating to the arts, history, geography, education, festivals, customs, and so on, while little "c" is viewed as the combination of attitudes or beliefs and assumptions which are at deeper level in comparison with the big " $\mathrm{C}$ " culture, and thus it is less visible. Peterson (2004) classified the culture relating to grand themes such as geography, architecture, classical music, literature, political issues, society's norms, legal foundation, core values, history, and cognitive processes into the category of Big "C" culture. For the little "c" culture, its focal is on common or minor themes which are listed as opinions, viewpoints, preferences or tastes, gestures, clothing styles, food, hobbies, and popular issues.

\section{B. Intercultural communicative competence and methods of developing ICC for EFL learners 1. Intercultural communicative competence}

Like culture, Intercultural Communicative Competence (ICC) is a complex concept and thus, there is not a complete agreement on the way it is defined. As Byram (1997, p. 7) suggested, ICC is "the ability to communicate and interact across cultural boundaries" which covers many components including linguistic competence, sociolinguistic competence, discourse competence, and intercultural competence. Additionally, Byram, Gribkova and Starkey (2002) further explained the notion of ICC as the ability to interculturally understand and interact with people who have multiple identities and distinct individuality from different societies. Guilherme (2000) maintained ICC enables effective interaction between people from different cultures. Likewise, Lázár et al. (2007) emphasized the effectiveness and appropriateness in communication donated by ICC in various intercultural situations and contexts. Despite the differences in conceptualizing ICC, it can be synthesized from those opinions that ICC requires necessary knowledge, attitudes, and skills in respect of linguistic and intercultural competence that assist language users from a certain culture to effectively and appropriately communicate with others from different cultural settings.

It is obvious that learning a foreign language requires not only knowledge about its linguistic system but also its cultural system. Lum (2004) asserted that real-life communication occurs within certain contexts and it is rarely culture-free since culture is part of most contexts. Accordingly, lacking understanding of differences in culture leads to misunderstanding in interaction between representatives of these cultural 
DOI: $\underline{10.51386 / 25815946 / \mathrm{ijsms}-\mathrm{v} 4 \mathrm{i} 5 \mathrm{p} 111}$

backgrounds. This raises the need for having understanding on both native and target culture to reinforce learners' ability to negotiate in communication. As being mentioned by scholars, this is making communication effective and appropriate in cultural diversity contexts. In other words, it is intercultural communicative competence. Traditionally, students are provided with vocabulary, grammar structures, phonetics, and so on. It is necessary for learners to understand language input, but it is definitely not enough. In reality, culture shock can occur even though the speaker is good at using language if he or she cannot adjust well when entering the target culture and still behaves with manners established in the source culture. As a result, learners should acknowledge intercultural communicative competence to deal with cultures shock (Teel \& Obidah, 2008). Moreover, ICC equips learners with critical awareness to distinguish beliefs, attitudes and behaviors appear in each culture (Holguin, 2013). In brief, ICC is an integral part that should be paid incremental attention in order to build fundamental background for EFL learners' attitudes, skills, and knowledge. As language and culture are inseparable, linguistic competence as well as ICC should be developed at the same time to assure the effect of language learning.

\section{Methods of developing ICC for EFL learners}

There are different ways and methods to help EFL learners to develop ICC. The methods presented in this section are most frequently recommended in the literature on ICC and ICC teaching.

\section{* Through Project-based learning}

In relation to the development of culture learning, Stern (1992) recommended eight techniques both applied for in-class and out-class situations. Concerning the in-class situation, the six techniques including creating an authentic classroom, providing activities with cultural information, involving cultural problem solving, engaging with behavioral and affective aspects using cognitive approaches, and providing the role of literature and humanities are involved. As for the latter group, two techniques: engaging with real-life exposure to the target culture and making use of cultural community resources in an English-speaking country are listed. Krajcik and Blumenfeld (2006) insisted that Project-based learning assists students' learning through requiring them to practice and apply their ideas on real world activities. This idea proves that PBL fixes well with the techniques mentioned before. It can be inferred that PBL creates an active and collaborative learning environment that brings students opportunities to intentionally use language within real-life contexts. This is also the time for them to see and learn from each other in different aspects such as lifestyles, way of thinking and solving problems, way of expressing ideas and negotiating with others, etc. Thanks to PBL, they can also recognize typical features or differences making every of them a unique identity. As a result, understanding and tolerance can be built as background for cultural awareness as well as ICC.

\section{* Through literature}

Literary works can connect students with the outside world where they cannot reach and nurture their soul with real life stories. Thanks to this, cultural values from different background are brought to students as sources of intercultural competence development. Lazar (1993) also mentioned that literature equips learners with authentic contexts which are meaningful and memorable so that they can assist language learning process.Collie and Slater (1987) suggested that literature should be incorporated in the classroom because of four main reasons. First, literature is a valuable authentic material. Second, it can enrich cultural understanding. Third, it is also a source for language enrichment. Finally, it benefits personal involvement. The advantages mentioned above contribute to the acknowledgement of literature's role in promoting learner's ICC.

\section{* Through cultural contents in teaching materials}

A great source of cultural contents comes from various teaching materials and textbooks turns out to be a dominant factor as McGrath (2002) emphasized that cultural content is included in textbooks. Lund (2006) explained textbooks assisted learners to be exposed to new cultural expressions and diversity of cultures by providing them with valuable inputs. As being seen by Cortazzi and Jin (1999) and Cortazzi (2000), teachers, students, and textbook are components of the three-party dialogue promoting culture learning.In summary, it is deniable that textbooks are a great source of both linguistic and cultural contents and thus, they play a vital role in developing learners' linguistic and intercultural competence. 
DOI: $\underline{10.51386 / 25815946 / \mathrm{ijsms}-\mathrm{v} 4 \mathrm{i} 5 \mathrm{p} 111}$

Volume: 4 Issue: 5

September to October 2021

https://www.ijsmsjournal.org

\section{The pilot English textbook series for high school students in Vietnam}

On the 30th of September, 2008, the National Project entitled Teaching and Learning Foreign Languages in the National Education System, Period 2008- 2020 was promulgated in Decision N ${ }^{\circ}$ 1400/QĐ-TTg by the Prime Minister of the Socialist Republic of Vietnam to have a reform on language teaching and learning. As a result, the series of English language textbooks are assigned to be written in order to meet the demand of the curriculum reform. For upper secondary level, the textbooks include Tiếng Anh 10, Tiếng Anh 11, and Tiếng Anh 12. This textbook series is designed with a clear set of principles.

Hoang $(2015$, p.6,7) cited the basic principles for designing the high school English program as below:

1. to ensure that the textbook series conforms to the guidelines and the learning outcomes should be aligned with those prescribed in MOET's three pilot English curricula and MOET'S VNFLPF.

2. to ensure that communicative language teaching and interactive learning are promoted.

3. to meet the English language learning needs of students of three different age ranges (primary [aged from 8-10], lower secondary [aged from 11-14], and upper secondary [aged from 15-17]) as well as their cognitive, social and affective needs.

4. to ensure that communicative competences are developed: focusing on the ability to communicate successfully using the lexical, phonological and grammatical language systems of English in meaningful contexts.

5. to ensure that the four communicative skills of listening, speaking, reading and writing are all developed in harmony and in appropriate proportion throughout primary, lower secondary and upper secondary levels and that cross-cultural issues are adequately incorporated into the contents of the textbooks.

6. to ensure that the whole textbook series is developed through coherent macrothemes and topics which are meaningful and relevant to Vietnamese school students'worlds and their future needs. These macrothemes and topics, when appropriate and possible, should be revisited throughout the primary, lower secondary and upper secondary grades to enable learning to be consolidated and to ensure the spiral nature of the textbook series.

7. to ensure that there is complete integration and articulation between the English textbooks for primary, lower secondary and upper secondary levels. This will include an integration of crosscurricular themes and topics whenever appropriate and possible.

8. to ensure that the textbooks should reflect cross-cultural values (Vietnamese, regional and AngloAmerican) across a wide range of contexts in Vietnam, in South-East Asia and in some main Englishspeaking countries.

In each grade level from 10 to 12 , the textbook is divided into two volumes which are in turn used for the two semesters. The first volume provides lessons in five units about the two themes: Our Lives and Our Society. The second volume works with the last two themes: Our Environment and Our Future within five units as well. Besides, there are four reviews in total (one after each theme) focusing on linguistic knowledge and skills learned in the lessons before.In terms of unit structure, there are eight lessons designed including: Getting Started, Language (Vocabulary, Pronunciation, and Grammar), Skills (Reading, Speaking, Listening, and Writing), Communication \& Culture, and Looking Back \& Project.

Hoang (2015) stated that "the best and most appropriate foreign language textbook(s) written exclusively for the general educational system of a country should be the one(s) developed cross-culturally by local authors and the authors who speak the foreign language as their mother tongue" (p.15). This is proven by the collaboration of Vietnam Education Publishing House and Pearson Education in developing the textbooks series. Going into details, the textbooks carry cultural contents from the source culture, the target culture, and the international culture integrated in the dialogues, texts, pictures, etc. The section Communication and Culture in each unit is supposed to be a representative which provides students with cultural knowledge from those sources. However, the extent to which cultural contents are conveyed through this part need to be further analyzed. 
DOI: $\underline{10.51386 / 25815946 / \mathrm{ijsms}-\mathrm{v} 4 \mathrm{i} 5 \mathrm{p} 111}$

Volume: 4 Issue: 5

September to October 2021

https://www.ijsmsjournal.org

\section{Related studies}

As the importance of developing learners' ICC has been well recognized, the role of textbooks in this field is also appraised. There has been more and more research on the cultural contents of EFL textbooks conducted all around the world.

A significant study on this topic is implemented by Xiao (2010). The study aimed to find out the categories of culture presented in an in-use textbook at university level of EFL in China, the types of culture presented in that textbook, students' perceptions and expectations towards the cultural contents in the book, and students' attitudes towards cultural learning and abilities on cultural implementation.

Musteata (2019) analyzed the cultural contents in two EFL Textbooks Used at SMA IT IQRA' (Pathway to English) and SMK N1 Grade Xin Bengkulu City to see the way cultural dimensions were displayed, the most dominant category among three types of culture namely source culture, local culture, and international culture, and the percentage of local culture presented in the textbooks.

In Vietnam, there are few studies focusing on the cultural contents presented in EFL textbooks. Through her research, Nguyen (2018) aimed to find out which type of culture among source culture, target culture, and international culture is the most dominant factor in the English textbook series under the ten-year curriculum used for high schools in Vietnam and how they are presented in those textbooks. The results showed that source culture and international culture got higher proportions in distribution with $34.4 \%$ and $32.2 \%$ respectively while target culture got less concern with $20.4 \%$. Besides, there are unidentified cultural contents which accounted for the last $15 \%$. One more important thing figured out by the researcher is that both Big C and little $\mathrm{c}$ culture were well presented in the textbooks with approximate proportion.

Similarly, Kieu (2021) conducted a study to investigate the presentation of intercultural components in the series of English textbooks used in Vietnamese high schools as a part of the National Foreign Language Project and to check whether these elements can benefit students in developing their ICC. Her findings showed that the cultural information is integrated through different sources such as target culture, source culture, international culture, intercultural interaction, and universality across culture in these textbooks. Finally, based on the findings, she affirmed that these textbooks which contain intercultural elements have contribution on students' ICC development.

Theories have pointed out the significance of teaching ICC to EFL learners and the importance of cultural contents in the teaching materials including textbooks. Research has focused on the way in which cultural contents are presented in textbooks, not much on how learners perceive these contents. It is rare to find a complete study on issues relating to students' attitude towards culture learning, especially in Vietnamese context, while as mentioned above, students' perception is also important and can positively donate to teaching strategies. Therefore, this study aimed to fill this gap by exploring what the cultural contents covered in the pilot English book series for high school students are and how they are perceived by Vietnamese high school EFL learners.

\section{A. Research design}

\section{RESEARCH METHODOLOGY}

This research is purely a descriptive study. Therefore, it should be comprehensible and informative. In an effort to address the three research questions, there is a need to triangulate the data collected as it was mentioned by Jick (1979, p.603) that this technique could "uncover some unique variance which otherwise may have been neglected by a single method". This leads to the application of mixed methods consist of quantitative and qualitative approach. Quantitative data is collected through Content analysis and questionnaires whereas qualitative data is gained through interviews. Table 3.1 below clearly distinguishes the methods used to collect data for each question.

\section{B. Participants}

This research called for the participation of 120 high school students who were learning with the pilot English textbooks 10, 11, and 12 in the Mekong Delta. The number of participants in each grade level was 40. At the first stage, they were asked to answer the questionnaire created by Google Form and sent via Zalo and Facebook. After this process, the semi-structured interviews were organized with participants who showed 
DOI: $\underline{10.51386 / 25815946 / \mathrm{ijsms}-\mathrm{v} 4 \mathrm{i} 5 \mathrm{p} 111}$

Volume: 4 Issue: 5

September to October 2021

https://www.ijsmsjournal.org

willingness by accepting the researcher's invitation. As a result, 12 students who are representatives for their grade level participated in the interview process. Specifically, there were 4 grade 10 students, 6 grade 11 students, and 2 grade 12 students took part in as interviewees. The time for administering the questionnaires and interviews was about at the end of the school year, so it was certain that the participants had learned all of the lessons and had knowledge about the issues related to cultural contents mentioned in the instruments.

\section{Research instruments}

\section{Content analysis}

Holsti (1968) defined content analysis as "any technique for making inferences by systematically and objectively identifying special characteristics of messages" (p.608). Frey, Botan, \& Kreps (1999) classify it into two categories based on the researcher's intention:

- Qualitative Content Analysis: the number of times message variables appear is less important to researchers than the meanings connected with them.

- Quantitative Content Analysis: the research questions and test hypothesis are answered systematically and step-by-step by the researchers.

In this study, although the frequency in the appearance of the sources and themes of culture presented in the textbook series was focused, the researcher paid more attention to the meaning behind it. Therefore, it was decided to be qualitative content analysis.

As mentioned in literature review, cultural contents were examined in terms of culture sources including target culture, source culture, and international culture as well as culture themes consisting of Big C and little c culture. The first step in this process was to map the cultural contents integrated in the section Communication and Culture in the textbook series with the themes and sources decided in a table. The cultural contents in each unit from each textbook were counted based on unit, then they were coded as clusters and placed in the table according to which type and category they belong to. Finally, they were analyzed using mathematics formula to conclude the percentage they account for in each item.

\section{Questionnaires}

Questionnaire can be considered as a useful tool in collecting data. Brown (2001) defined questionnaires as one of the most commonly used methods in research which contain a collection of questions or statements requiring the respondents to give answers to or to express their level of agreement. A striking point for using questionnaires is that it allows participants to have time for considering the questions as well as their answers (Edward, 1991). Besides, McKay and Gass (2005) added questionnaires can be used to investigate a wide variety of questions in second language research. In this study, the questionnaire was adapted from Jing Xiao's (2010) questionnaire and it contained three clusters. The first cluster consisted of 6 items as in Jing Xiao's (2010) questionnaire. They were about students' opinion about the importance of culture learning. The second clusters was designed with 10 items trying to figure out students' opinion about the content of the section Communication and Culture in the textbook Tieng Anh 10/ Tieng Anh 11/ Tieng Anh 12. The statements were redesigned with items $8,9,10,11$, and 15 being added to help figure out the issues mentioned in the research questions. The last cluster with 9 items was used to investigate students' opinion about the usefulness of cultural contents provided in the Communication and Culture sections. This part was designed by the researcher based on the research question. All of the items in this section were designed using Likert-Scale model with 5 options provided ranging from Strongly disagree to Strongly agree.

\section{Interviews}

Although it is hard to connect a wide range of participants as what questionnaires can do, it is noteworthy that interviews can be useful in assisting researchers to gain in-depth information about the concerned issue. Also, an interview can help in expanding understanding from the quantitative result bringing by questionnaires (Gillham, 2008). In this research, a semi-structured interview was applied in order to get insights into the participants' responses. Based on the aims of the study, 3 interview questions were designed as the main items for interviewing. Specifically, the first question investigated whether the students were satisfied with the cultural contents integrated into their English textbooks. The next question asked for students' evaluation of the strengths and weaknesses of those contents. The third question explored students' 
DOI: $\underline{10.51386 / 25815946 / \mathrm{ijsms}-\mathrm{v} 4 \mathrm{i} 5 \mathrm{p} 111}$

Volume: 4 Issue: 5

September to October 2021

https://www.ijsmsjournal.org

judgment about the way these cultural contents were presented. Besides, the researcher also asked subsequent questions to make sure or clarify interviewees' ideas. All of the questions were transcribed into Vietnamese to help the interviewees understand easily.

\section{FINDINGS AND DISCUSSIONS}

A. Cultural contents presented in the section Communication and Culture in the pilot English textbook series or upper secondary level

For the purpose of scrutinizing the cultural contents in the textbook series, the researcher made use of mapping technique. In the Culture part of each unit, the cultural contents were classified into categories including Target culture, Source culture, and International culture and themes belonging to Big $\mathrm{C}$ culture and Little c culture. Whenever the contents met the standard of each category or type, they were marked by $(\checkmark)$. After finishing, the results were calculated into percentage. The results indicated that there is a significant inequality in the distribution of sources and themes of culture in all three levels. The first striking point is that target culture accounts for the least proportion in all grades while international culture almost got the highest percentage except for that in grade 12. Besides, source culture is at an average level for grades 10 and 11. There is an exchange in the division of source culture and international culture in the textbooks of grades 11 and 12 whilst it remains unchanged for the category of the target culture.

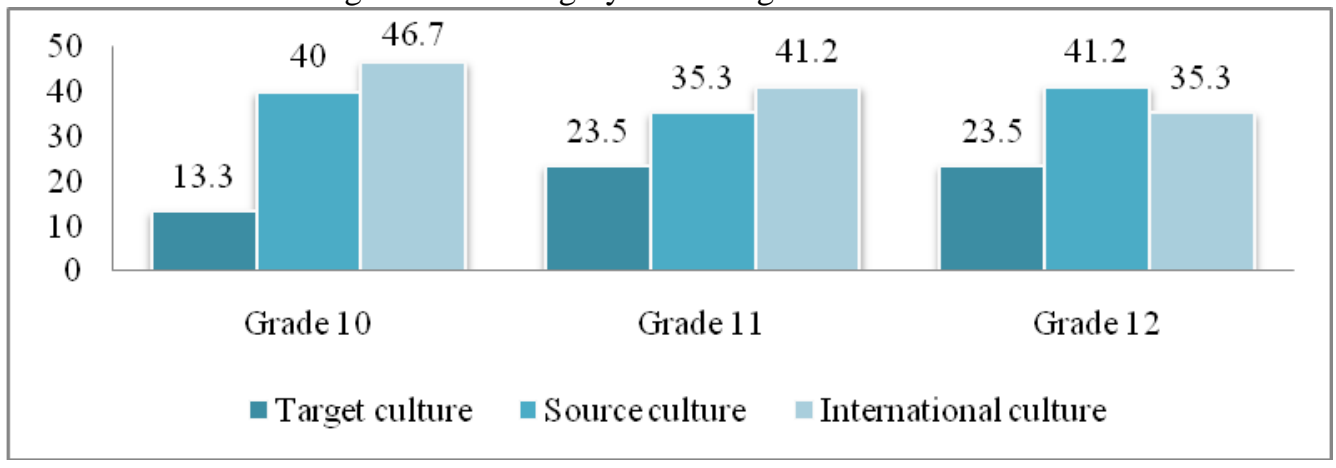

Figure 1: Categories of Culture sources presented in Communication and Culture sections

Regarding the culture themes, the topic of each culture lesson is closely related to the unit's topic. They are diverse with various themes involving Lifestyles, Social norms, Values, Customs, Education, History, Politics, Geography, Economy, Literature/Art, Architecture, Food, Festivals, Inventions, and Environment. Little c culture's percentage outweighs Big C culture's proportion in all 3 grades. In short, the way culture is presented in the Tieng Anh textbook series is imbalanced. In conclusion, International culture and Little c culture account for a large proportion and the cultural features related to the target language are less noticeable in the section Communication and Culture.

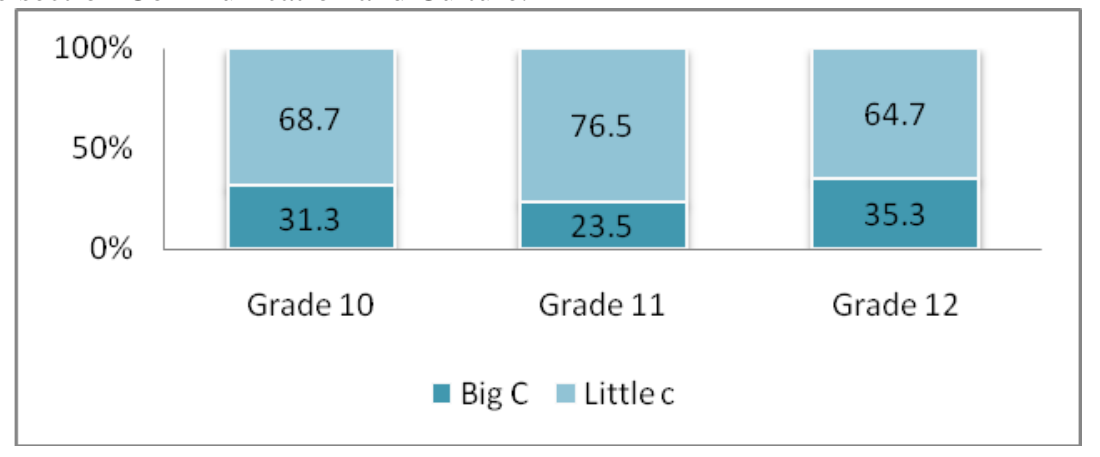

Figure 2: Themes of Culture presented in Communication and Culture sections

\section{B. Students' perception towards the cultural contents in the section Communication and Culture in the pilot English textbook series used for upper secondary level}

The first part of the questionnaire with 3 clusters helps gather information about students' perception. The first cluster investigates learners' perspectives about the importance of learning culture. Students' opinion about the way cultural contents are introduced in the section Communication and Culture is illustrated in the 
DOI: $\underline{10.51386 / 25815946 / \mathrm{ijsms}-\mathrm{v} 4 \mathrm{i} 5 \mathrm{p} 111}$

Volume: 4 Issue: 5

September to October 2021

https://www.ijsmsjournal.org

second cluster. Finally, the third cluster seeks to examine students' evaluation of the usefulness of the section. These clusters were reliable since the Cronbach's alpha for each of them was .71, .88, and .88 respectively. In order to inspect the result related to students' perception towards cultural contents in the textbooks, the Descriptive statistics test was used to calculate the Min, Max, Means and SD of the three clusters. The mean scores of the clusters are 4.3,3.9, and 4.1 respectively which lead to the initial conclusion that students have positive attitudes towards the issues being studied.

A One-Sample T-test was conducted to figure out whether the mean score of each cluster and the test value 4.5 which was defined as the lowest point in the scale of Very high level by Oxford (1990) was different. The results indicated that they are completely different. Therefore, it can be concluded that students' perception of learning culture is positive and their evaluation of the section Communication and Culture as well as the cultural contents in this section is quite good.

Aiming at finding out if there are differences in students' perception among levels, One-way ANOVA test was used with three pairs of students including grade 10 and grade 11 , grade 10 and grade 12, and grade 11 and grade 12. The results proved that students in grades 11 and 12 have similar viewpoint about learning culture while those who are in grade 10 have different perspectives in comparison with them. The same situation occurred with the other two clusters concerning their evaluation on the section Communication and Culture and its cultural contents. Table 1 below presents the calculated results:

TABLE 1

ONE-WAY ANOVA TEST RESULTS FOR CLUSTER 1, 2, AND 3

\begin{tabular}{|c|c|c|c|c|c|c|}
\hline Cluster & Pair & Class & $\mathbf{N}$ & Mean & SD & $\mathbf{p}$ \\
\hline \multirow{3}{*}{1} & Pair 1 & $10-11$ & \multirow{3}{*}{$40-40$} & $4.58-4.25$ & $.36-.55$ & .01 \\
\hline & Pair 2 & $10-12$ & & $4.58-4.13$ & $.36-.47$ & .00 \\
\hline & Pair 3 & $11-12$ & & $4.25-4.13$ & $.55-.47$ & .65 \\
\hline \multirow{3}{*}{2} & Pair 1 & $10-11$ & \multirow{3}{*}{$40-40$} & $4.17-3.80$ & $.54-.72$ & .04 \\
\hline & Pair 2 & $10-12$ & & $4.17-3.74$ & $.54-.64$ & .01 \\
\hline & Pair 3 & $11-12$ & & $3.80-3.74$ & $.72-.64$ & .96 \\
\hline \multirow{3}{*}{3} & Pair 1 & $10-11$ & \multirow{3}{*}{$40-40$} & $4.36-3.93$ & $.53-.70$ & .01 \\
\hline & Pair 2 & $10-12$ & & $4.36-3.99$ & $.53-.66$ & .02 \\
\hline & Pair 3 & $11-12$ & & $3.93-3.99$ & $.70-.66$ & .97 \\
\hline
\end{tabular}

It can be seen that although all students have positive attitude towards the clusters, students in grade 10 showed that their evaluation of each cluster is on higher level than students in grades 11 and 12. Based on this conclusion, a hypothesis is made that there is a correlation between students' point of view about cultural learning and their way of assessment on the section Communication and Culture and the cultural contents in this part. A correlation test was carried out to scrutinized this hypothesis and the result informed that there is a strong interaction between the variables $(\mathrm{r}=.74, \mathrm{p}=.00$ for the test between cluster 1 and 2 and $\mathrm{r}=.56, \mathrm{p}$ $=.00$ for the test between cluster 1 and 3 ).

The Descriptive statistics test was performed to get insight into students' viewpoints about related issues being questioned in each cluster. Regarding the way students perceive cultural learning importance, the figuresillustrated that they have a strong desire for having knowledge of Vietnamese culture $(\mathrm{M}=4.82)$ whilst the international culture $(\mathrm{M}=3.64)$ seems to be underrated compared to the other two categories. Besides, they showed preference on topics concerning daily living and cultural patterns rather than those of politics, economy, or science. 
DOI: $\underline{10.51386 / 25815946 / \mathrm{ijsms}-\mathrm{v} 4 \mathrm{i} 5 \mathrm{p} 111}$

Volume: 4 Issue: 5

TABLE 2 DESCRIPTIVE STATISTICS OF THE QUESTIONS IN CLUSTER 1

\begin{tabular}{|c|c|c|c|c|c|}
\hline & $\mathbf{N}$ & Min & Max & Mean & $\begin{array}{c}\text { Std. } \\
\text { Deviation }\end{array}$ \\
\hline $\begin{array}{l}\text { 1. I want to learn cultural contents as well as language } \\
\text { knowledge. }\end{array}$ & 120 & 1 & 5 & 4.41 & .794 \\
\hline $\begin{array}{l}\text { 2. It is very important for me to know the culture of } \\
\text { English speaking countries, such as England, America, and } \\
\text { Australia. }\end{array}$ & 120 & 1 & 5 & 4.29 & .854 \\
\hline 3. It is very important for me to know Vietnamese culture. & 120 & 3 & 5 & 4.82 & .467 \\
\hline $\begin{array}{l}\text { 4. It is very important for me to know the culture of non- } \\
\text { English speaking countries, such as Thailand, Chinese, and } \\
\text { Brazil. }\end{array}$ & 120 & 1 & 5 & 3.64 & .977 \\
\hline $\begin{array}{l}\text { 5. It is very important for me to know about the products } \\
\text { and contribution to a society, such as politics, economy, } \\
\text { history, literature, sciences and geography. }\end{array}$ & 120 & 2 & 5 & 4.31 & .786 \\
\hline $\begin{array}{l}\text { 6. It is very important for me to know about daily living } \\
\text { and culture patterns, such as food, holidays, lifestyles, and } \\
\text { customs. }\end{array}$ & 120 & 2 & 5 & 4.43 & .742 \\
\hline
\end{tabular}

Turning on how students evaluated the presentation of cultural contents in Communication and Culture part, most of the items mentioned were highly agreed by the students except for statements 12,13 , and 14 about the distribution of culture sources through the section. It can be seen that the mean scores for these three items descend gradually from 3.73 for English speaking countries to 3.21 for Vietnam and 2.88 for nonEnglish speaking countries.

TABLE 3

DESCRIPTIVE STATISTICS OF THE QUESTIONS IN CLUSTER 2

\begin{tabular}{|c|c|c|c|c|c|}
\hline & $\mathbf{N}$ & Min & Max & Mean & $\begin{array}{c}\text { Std. } \\
\text { Deviation }\end{array}$ \\
\hline 7. A variety of different cultures is presented. & 120 & 2 & 5 & 4.13 & .721 \\
\hline 8. The culture presented in each section is interesting. & 120 & 1 & 5 & 4.12 & .891 \\
\hline $\begin{array}{l}\text { 9. The culture presented in each section is closely } \\
\text { related to the theme or topic of the unit. }\end{array}$ & 120 & 3 & 5 & 4.33 & .712 \\
\hline $\begin{array}{l}\text { 10. Cultural contents are presented through easy to } \\
\text { understand reading texts or dialogues. }\end{array}$ & 120 & 2 & 5 & 4.17 & .863 \\
\hline $\begin{array}{l}\text { 11. Cultural contents are supported by related pictures } \\
\text { or diagrams. }\end{array}$ & 120 & 2 & 5 & 4.33 & .803 \\
\hline
\end{tabular}


DOI: $\underline{10.51386 / 25815946 / \mathrm{ijsms}-\mathrm{v} 4 \mathrm{i} 5 \mathrm{p} 111}$

Volume: 4 Issue: 5

September to October 2021

https://www.ijsmsjournal.org

\begin{tabular}{|c|c|c|c|c|c|}
\hline $\begin{array}{l}\text { 12. The culture of English speaking countries was } \\
\text { mainly focused upon. }\end{array}$ & 120 & 1 & 5 & 3.73 & 1.174 \\
\hline 13. Vietnamese culture was mainly focus upon. & 120 & 1 & 5 & 3.21 & 1.194 \\
\hline $\begin{array}{l}\text { 14. The culture of non-English speaking countries was } \\
\text { mainly focused upon. }\end{array}$ & 120 & 1 & 5 & 2.88 & 1.258 \\
\hline $\begin{array}{l}\text { 15. The tasks designed in this section help me to figure } \\
\text { out the culture intended to be introduced. }\end{array}$ & 120 & 1 & 5 & 4.08 & .881 \\
\hline 16. The tasks are varied in form. & 120 & 1 & 5 & 4.04 & 902 \\
\hline
\end{tabular}

To specifically visualize the description, the Frequencies test was run for all the statements of this cluster. The findings informed that most students believed that the proportion of English speaking countries' culture is mostly placed in the section Communication and Culture (28.3\% for Agree and 32.5\% for Strongly agree). Nevertheless, among the options ranged from Strongly disagree to Strongly agree, students have a tendency to choose Neutral with $36.6 \%$ for non-English speaking countries, $31.7 \%$ for Vietnam, and even $23.3 \%$ for English speaking countries, which means they felt unsure about the answers. The percentages are also respectively high for students' disagreement, especially for the categories of non- English speaking countries (15\% Strongly disagree, 23.3\% Disagree) and Vietnam (7.5\% Strongly disagree, $21.7 \%$ Disagree).

In respect of the section's usefulness, the computed figures presented in Table 4showthat it is acknowledged by the students. Besides, they maintained the cultural contents are mainly in relation to English speaking countries' culture $\left(\mathrm{M}_{17}=4.11, \mathrm{M}_{18}=4.33\right)$, followed by Vietnam's $\left(\mathrm{M}_{19}=3.95, \mathrm{M} 20=4.06\right)$, and the least segment goes to Non- English speaking countries' $\left(\mathrm{M}_{21}=3.6,0 \mathrm{M}_{22}=3.76\right)$.

\section{TABLE 4}

DESCRIPTIVE STATISTICS OF THE QUESTIONS IN CLUSTER 3

\begin{tabular}{|l|r|r|r|r|c|}
\hline & N & Min & Max & Mean & $\begin{array}{c}\text { Std. } \\
\text { Deviation }\end{array}$ \\
\hline $\begin{array}{l}\text { 17. The section provided me with knowledge of the } \\
\text { products and contribution to the society, such as politics } \\
\text { and economy, of English speaking countries in English. }\end{array}$ & 120 & 2 & 5 & 4.11 & .797 \\
\hline $\begin{array}{l}\text { 18. The section provided me with knowledge of daily } \\
\text { living and culture patterns, such as food and holidays, of } \\
\text { English speaking countries in English. }\end{array}$ & 120 & 2 & 5 & 4.33 & .758 \\
\hline $\begin{array}{l}\text { 19. The section provided me with knowledge of the } \\
\text { products and contribution to the society, such as politics } \\
\text { and economy, of Vietnam in English. }\end{array}$ & 120 & 1 & 5 & 3.95 & .977 \\
\hline $\begin{array}{l}\text { 20. The section provided me with knowledge of daily } \\
\text { living and culture patterns, such as food and holidays, of } \\
\text { Vietnam in English. }\end{array}$ & 120 & 1 & 5 & 4.06 & .873 \\
\hline
\end{tabular}


DOI: $\underline{10.51386 / 25815946 / \mathrm{ijsms}-\mathrm{v} 4 \mathrm{i} 5 \mathrm{p} 111}$

Volume: 4 Issue: 5

September to October 2021

https://www.ijsmsjournal.org

\begin{tabular}{|c|c|c|c|c|c|}
\hline $\begin{array}{l}\text { 21. The section provided me with knowledge of the } \\
\text { products and contribution to the society, such as politics } \\
\text { and economy, of non-English speaking countries in } \\
\text { English. }\end{array}$ & 120 & 1 & 5 & 3.60 & 1.103 \\
\hline $\begin{array}{l}\text { 22. The section provided me with knowledge of daily } \\
\text { living and culture patterns, such as food and holidays, of } \\
\text { non-English speaking countries in English. }\end{array}$ & 120 & 1 & 5 & 3.76 & 1.123 \\
\hline $\begin{array}{l}\text { 23. Knowledge of culture helps me to understand } \\
\text { language better. }\end{array}$ & 120 & 2 & 5 & 4.39 & .873 \\
\hline $\begin{array}{l}\text { 24. Knowledge of culture helps me to be tolerant to } \\
\text { others. }\end{array}$ & 120 & 1 & 5 & 4.13 & .961 \\
\hline $\begin{array}{l}\text { 25. Knowledge of culture helps me to communicate more } \\
\text { effectively. }\end{array}$ & 120 & 2 & 5 & 4.53 & .709 \\
\hline
\end{tabular}

The data collected through interviews also helped in defining students' attitudes towards the importance of learning culture as well as the cultural contents in Communication and Culture section and the way they are presented. Firstly, all of the participants agreed that learning culture is important in learning a foreign language. It can also help in communication with people from a different culture. They expressed:

"It is very important and necessary to learn about culture because we can have more topics in common with other people and we can avoid impolite behaviors because something may be normal in another culture, however it is an insult in the culture of the people we are talking with" (S1)

"When we learn a language, we need to know about their culture to understand deeper and explore more... We can be more confident and easy to integrate with the community" (S4)

Discussing the role of the section Communication and Culture in the Tieng Anh textbook series in comparison with students' perspectives of cultural learning, the students revealed that the section provided them with basic information about culture. Primarily, it carried the cultural contents rather well. Below are positive comments about it.

"I am satisfied with this part because it helps me to know more about the lesson as well as how to communicate culturally and improve our life better" (S5)

"The books talk about the culture of some countries and I think they did the job well"... "Its strength is that it gives me a lot of knowledge including knowledge about foreign countries, and when I read it, if I feel good, I will find out more about the country that the Communication section mentions" (S6).

However, most of the students expected changes or improvements in the matter of the topics of the cultural contents conveyed in the session as well as the way they are introduced.

"To some extent, it can provide knowledge of culture; however, it is still not enough. I would like it to be added more about the way to talk to others like how to behave to express respect to others" [...] "I am overloaded with the number of words in the texts, they are too much... It makes me dizzy. However, they do not focus much about the topic of culture they are intended to introduce" (S1)

"I find that they present this text a little bit boring and it lacks attraction to us, the information given is quite basic that most of us already know, so it didn't stimulate our curiosity" [...] "I am not really satisfied with this because it has too many words. It is better if there are more pictures and students should have chances to practice"[...] "There are few pictures [...] it makes students hard to visualize the cultural features" (S3).

Other students expressed some dissatisfaction about the way cultural contents associated with different areas distributed in the textbooks.

"I hope there will be more knowledge about Vietnamese culture added" (S7)

"Instead of focusing on culture of English speaking countries and Vietnam, non-English speaking countries' culture should be developed because it is not much" (S8)

"I fell it is unclear. It does not differentiate between the cultures of different places" (S10) 
DOI: $\underline{10.51386 / 25815946 / \mathrm{ijsms}-\mathrm{v} 4 \mathrm{i} 5 \mathrm{p} 111}$

Volume: 4 Issue: 5

September to October 2021

https://www.ijsmsjournal.org

\section{Discussion}

- In comparison with previous studies in similar aspects conducted by Nguyen (2018) and Kieu (2021), the findings of this research meet their results at some points. Both the aforementioned research also found that target culture is at the lowest rank among the three components, albeit their scopes of study are wider all sections of each unit in the textbooks are investigated. Specifically, in Nguyen's (2018) study, she proved Big C culture accounts for less proportion than little $\mathrm{c}$ culture across the program. The above findings are in alignment with the principles for designing the high school English program cited by Hoang (2015, p.6-7) that the textbooks are expected to provide students with an incorporation of cross-cultural issues in Vietnam, South-East Asia countries, and English speaking countries. However, with the imbalance distribution as mentioned, there is no assurance for the adequacy of these sources. Chao (2011) asserted that it is essential to balance the distribution of source culture, target culture and international culture in the content arrangement of ELT textbooks. It can be synthesized that the role of both target culture and source culture in learning language is crucial and undeniable. Regarding the contribution of Big $\mathrm{C}$ and little c culture in culture learning, scholars have emphasized the prominent role of little c culture. Lee (2009) insisted that little c culture can effectively help students to promote their understanding on how people in the target context use language to function in daily communication which results in developing ICC. This idea is also in line with Winterwgerst and McVeigh (2010). It is reasonable for the disproportion of Big C and little $\mathrm{c}$ in the textbook in this research. The processing of data from questionnaire brought the finding that the majority of the students show positive attitudes towards the section since it can provide them with a basic understanding of culture. This idea is again supported when they were interviewed. This finding is concurrent with Kahraman (2016), Belli (2018), and James and Aziz (2020) that the students show supportive attitude to cultural learning in language classrooms. This is an encouraging sign for ICC development. However, the students also pointed out dissatisfactions in terms of favorite sources and themes of culture that need to be improved which showed highlights of their understanding and interests of learning culture. In general, it is necessary to reconsider the way culture sources are addressed as well as how culture is presented in the textbooks since learners' motivation can be enhanced when cultural components are integrated in language teaching materials (Gardner \& Lambert, 1972 and Adaskou, Britten, and Fahsi, 1990).

\section{CONCLUSIONS AND IMPLICATIONS}

As emphasized by scholars, learning a language effectively requires the integration of culture as a key domain and it is ideal with the combination of knowledge of all sources and themes of culture. Based on the findings, it is clear that the section Communication and Culture focused mostly on the international culture and little c culture. Although the perfect division for these categories and types of culture has not been affirmed in any research, it is essential to minimize the imbalance between them. Students' reflections showed that this disproportion becomes inconsistent with their expectations. In addition, learning should be active and interesting. Students need to get exposed to authentic materials with meaningful tasks in an interactive context. They require diverse yet selective cultural contents which are also impressive and motivating. Thus, supportive means including textual and visual sources are in need of better improvements. As a result, it is noticeable for addressing these findings in curriculum development, course design, or textbook compilation.

Cortazzi and Jin (1999) proposed that the textbook has different roles including considering it as a teacher. Nevertheless, it cannot completely replace the teacher in students' learning process. The teacher should be aware of shortcoming in the materials as well as students' needs and limitations to have appropriate adjustments. It is hard to affirm a textbook is perfectly suit the educational program and students always have high expectation on teacher performances. They are not only instructors or facilitators but also inspirers. Hence, teachers' acknowledgement of these issues can assist their teaching practices with better preparations, especially in terms of cultural knowledge.

Students can be benefitted from both textbook knowledge and teacher's instructions, however, they cannot be just passive receivers. They can take advantage of understanding their own necessity as well as knowing the section's strengths and weaknesses to have well-prepared plans for their self-study. Culture derives from 


\section{DOI: $\underline{10.51386 / 25815946 / i j s m s-v 4 i 5 p 111}$}

people's life, it is not difficult to explore or experience. There are several sources for students to widen their knowledge about culture. They should reflect on their learning to be conscious of what they know well and what they do not in order to have suitable revisions.

\section{ABOUT THE AUTHOR}

Dinh Thi Truc Linh is currently pursuing her Master's at Can Tho University, Viet Nam. She completed a bachelor's degree in English in Education in 2013. Her research interests consist of culture teaching, teaching methodologies, and teacher and learner's motivation.

\section{REFERENCES}

[1] Adaskou,K., Britten,D. \& Fahsi, B. (1990). Design decision on the culture content of a secondary English course for Morocco. ELT Journal, 44 (1).

[2] Avruch, K. (1998). Culture \& Conflict Resolution (p. 6). United States Inst of Peace Press.

[3] Belli, S. A. (2018). A study on ELT students" cultural awareness and attitudes towards incorporation of target culture into language instruction. Journal of Language and Linguistic Studies, 14(1), 102-124.

[4] Brown, H. D. (1994b). Principles of Language Learning and Teaching (2nd ed.). Prentice Hall.

[5] Brown, J. D. (2001). Using surveys in language programs. Cambridge university press.

[6] Byram, M. (1997). Teaching and assessing intercultural communicative competence. Multilingual Matters.

[7] Byram, M., Gribkova, B., \& Starkey, H. (2002). Developing the intercultural dimension in language teaching: A practical introduction for teachers. Language Policy Division, Directorate of School, Out-of-School and Higher Education, Council of Europe.

[8] Chao, T. C. (2011). The hidden curriculum of cultural content in internationally published ELT textbooks: A closer look at new American inside out. Journal of Asia TEFL, 8(2), 189-210.

[9] Collie, J., \& Slater, S. (1987). Literature in the Language Classroom. Cambridge University Press.

[10] Cortazzi, M., \&Jin, L. (1999). Cultural mirrors: Materials and methods in the EFL classroom. In E. Hinkel (Ed.), Culture in second language teaching and learning (pp. 196-219). New York, NY: Cambridge University Press

[11] Cortazzi, M. (2000). Languages, cultures, and cultures of learning in the global classroom. Anthology Series-Seameo Regional Language Centre, 75-103.

[12] Edwards, J. (1991). Evaluation in adult and further education: a practical handbook for teacher and organizer. Workers' Educational Association.

[13] Frey, L., Botan, C., \& Kreps, G. (1999). Investigating communication: An introduction to research methods (2nd ed.). Bosten: Allyn and Bacon.

[14] Gardner, R. C.,\& Lambert, W, E (1972). Motivational variables in second language acquisition. Rowley, MA: Newbury House.

[15] Guilherme, M. (2000). Intercultural competence. In M. Byram (ed.) Routledge Encyclopaedia of Language Teaching and Learning (pp. 297-300). London: Routledge

[16] Ha, K. (2021). An investigation into intercultural components in three piloted English textbooks for Vietnamese high schools under the national foreign languages project. VNU Journal Of Foreign Studies, 37(1). doi:10.25073/2525-2445/vnufs.4655

[17] Holguín, B. R. (2013). Towards the development of intercultural competence skills: A pedagogical experience with pre-service teachers. HOW Journal, 20(1), 206-225.

[18] Holsti, O.R. (1968). Content Analysis. In G.Lindzey \& E.Aronson (Eds.), The Handbook of Social Psychology (2nd ed.) (Pp.596692), Vol.II, New Delhi: Amerind Publishing Co.

[19] James, P. R., \& Aziz, A. A. (2020). Perceptions and Expectancies of Malaysian Students on Cultural Elements in Foreign Textbooks. International Journal of Academic Research in Business and Social Sciences, 10(4), 214-231.

[20] Jick, T. D. (1979). Mixing qualitative and quantitative methods: Triangulation in action. Administrative science quarterly, 24(4), 602-611. 


\section{DOI: $\underline{10.51386 / 25815946 / \mathrm{ijsms}-\mathrm{v} 4 \mathrm{i} 5 \mathrm{p} 111}$}

Volume: 4 Issue: 5

September to October 2021

https://www.ijsmsjournal.org

[21] Kahraman, A. (2016). Teacherse ${ }^{\text {ee }}$ and Learnerse Attitudes towards Culture and Culture Learning in a Turkish Context. Journal of Language and Linguistic Studies, 12(2), 01-12.

[22] Krajcik, J. S., \& Blumenfeld, P. C. (2006). Project-based learning (pp. 317-34). na.

[23] Lazar, G.(1993). Literature and language teaching. Cambridge, M.A.: Cambridge University Press.

[24] Lázár I. and Huber-Kriegler, M., Lussier, D., Matei, G. S., Peck, C. (Eds.) (2007). Developing and assessing intercultural communicative competence - A guide for language teachers and teacher educators. European Centre for Modern Languages. Strasbourg: Council of Europe

[25] Lee, K. Y. (2009). Treating culture: What 11 high school EFL conversation textbooks in South Korea Do, English Teaching: Practice And Critique, 8(1) 76-96.

[26] Lund, R. (2006). Questions of culture and context in English language textbooks: A study of textbooks for the teaching of English in Norway. A Dissertation in Universitet I Bergen. Bergen:Unpublished.

[27] Mackey, A. and Gass, S. (2005). Second language research: Methodology and design. New York: Routledge.

[28] McGrath, I. (2002). Materials evaluation and design for language teaching. Edinburgh University Press.

[29] Montgomery, M., Reid-Thomas, H., Cameron, D., Corbett, J., \&Maley, W. (1994). Language and social life. British Council.

[30] Mustofa, M. I., \& Martina, F. (2019). The analysis of cultural content in two EFL textbooks used at SMA IT IQRA'And SMKN 1 Bengkulu City. Journal of English Education and Teaching, 3(4), 481-493.

[31] Nelson, G. (1995). Considering culture: Guidelines for ESL/EFL textbook writers. Material writer's guide, $23-44$.

[32] Nguyen, T.H.H. (2018). A study on the features of source culture, target culture and international culture presented in textbook Tieng Anh 10, Tieng Anh 11 and Tieng Anh 12 of the ten-year curriculum. (MA thesis). Retrieved from https://repository.vnu.edu.vn/flowpaper/simple_document.php?subfolder=15/73/26/\&doc=15732641676489369426186764316461 2714537\&bitsid=953a203d-da8b-4842-9471-ac759d78ff99\&uid=

[33] No, D. (2020). 1400/QĐ-TTg (2008). Teaching and Learning of English in the National Education System in Period 2008-2020.

[34] Peterson, B. (2004). Cultural intelligence: A guide to working with people from other culture. Yarmouth, ME: Intercultural Press.

[35] Stern, H.(1992). Issues and options in language teaching. Oxford: Oxford University Press.

[36] Teel, K. M., Obidah, J. E., Lytle, S. L., \& Cochran-Smith, M. (Eds.). (2008). Building racial and cultural competence in the classroom: Strategies for urban educators. Teachers College Press.

[37] Tylor, E. B. (1871). Primitive culture: Researches into the development of mythology, philosophy, religion, art and custom (Vol. 2). J. Murray.

[38] Vân, H. V. (2015). The development of the ten-year English textbook series for Vietnamese schools under the National Foreign Language 2020 Project: A cross-cultural collaborative experience. VNU Journal of Foreign Studies, 31(3).

[39] Wintergerst, A. C., \& McVeigh, J. (2010). Tips for teaching culture: A practical approach to intercultural communication. White Plains, NY: Pearson Longman.

[40] Xiao, J. (2010). Cultural contents of an in-use EFL textbook and English major students' attitudes and perceptions towards culture learning at Jiangxi University of Science and Technology, China (Doctoral dissertation, Prince of Songkla University). 